\title{
"Ethics, resource rent, environment and petroleum policy: the case of a small open economy"
}

\begin{tabular}{|c|c|c|}
\hline AUTHORS & \multicolumn{2}{|l|}{$\begin{array}{l}\text { Ola Honningdal Grytten (iD) } \\
\mathbb{R} \\
\text { John Arngrim Hunnes (iD) }\end{array}$} \\
\hline ARTICLE INFO & \multicolumn{2}{|c|}{$\begin{array}{l}\text { Ola Honningdal Grytten and John Arngrim Hunnes (2021). Ethics, resource rent, } \\
\text { environment and petroleum policy: the case of a small open economy. } \\
\text { Environmental Economics, 12(1), 76-89. doi:10.21511/ee.12(1).2021.07 }\end{array}$} \\
\hline DOI & \multicolumn{2}{|c|}{ http://dx.doi.org/10.21511/ee.12(1).2021.07 } \\
\hline RELEASED ON & \multicolumn{2}{|l|}{ Thursday, 01 July 2021} \\
\hline RECEIVED ON & \multicolumn{2}{|l|}{ Wednesday, 19 May 2021} \\
\hline ACCEPTED ON & \multicolumn{2}{|l|}{ Friday, 25 June 2021} \\
\hline LICENSE & \multicolumn{2}{|c|}{$\begin{array}{l}\text { This work is licensed under a Creative Commons Attribution } 4.0 \text { International } \\
\text { License }\end{array}$} \\
\hline JOURNAL & \multicolumn{2}{|l|}{ "Environmental Economics" } \\
\hline ISSN PRINT & \multicolumn{2}{|l|}{$1998-6041$} \\
\hline ISSN ONLINE & \multicolumn{2}{|l|}{$1998-605 X$} \\
\hline PUBLISHER & \multicolumn{2}{|c|}{ LLC "Consulting Publishing Company "Business Perspectives" } \\
\hline FOUNDER & \multicolumn{2}{|c|}{ LLC "Consulting Publishing Company "Business Perspectives" } \\
\hline 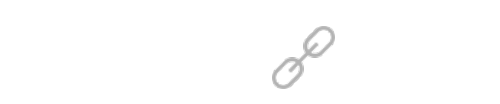 & 15 & ニ泣 \\
\hline NUMBER OF REFERENCES & NUMBER OF FIGURES & NUMBER OF TABLES \\
\hline 40 & 4 & 3 \\
\hline
\end{tabular}

(C) The author(s) 2022. This publication is an open access article. 


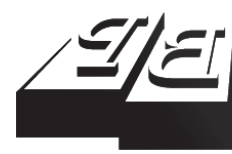

\section{BUSINESS PERSPECTIVES}

LLC "CPC "Business Perspectives" Hryhorii Skovoroda lane, 10, Sumy, 40022, Ukraine www.businessperspectives.org
Received on: $19^{\text {th }}$ of May, 2021 Accepted on: $25^{\text {th }}$ of June, 2021 Published on: $1^{\text {st }}$ of July, 2021

(c) Ola Honningdal Grytten, John Arngrim Hunnes, 2021

Ola Honningdal Grytten, Dr Oecon, Professor, Faculty of Economics, Department of Economics, Norwegian School of Economics, Norway. (Corresponding author)

John Arngrim Hunnes, Dr Oecon, Associate Professor, Department of Management, University of Agder, Norway.

Ola Honningdal Grytten (Norway), John Arngrim Hunnes (Norway)

\title{
ETHICS, RESOURCE RENT, ENVIRONMENT AND PETROLEUM POLICY: THE CASE OF A SMALL OPEN ECONOMY
}

\begin{abstract}
This paper contributes to the understanding of how the environment, ethics, values, and historical contingencies shape public policy. It explains the accomplishment of petroleum resource management in the small open economy of Norway. The study is conducted by mapping policy decisions and the arguments behind them regarding environmental and ethical issues. This is done by studying available governmental and parliamentary papers along with statements from politicians and central governmental officials. The paper also seeks to illuminate some of the decisions by quantitative measures.

The paper firstly describes a model of Ricardian resource rent. Secondly, it investigates the set of values that were in place before the petroleum production started in the 1970s, as described in public documents. An important argument was to build a "qualitatively better society" for the benefit of the people. Thirdly, it traces the historical roots of these values by examining historical sources.

The main findings are that success lies in understanding the ethics behind the environmental resource rent harvesting of this non-renewable natural resource. The paper concludes that the focus on the natural environment and resource rent management can be attributed to popular values built on historical traditions. According to them, the state and the trust between the state and its citizens played key roles in shaping the policy. The careful policy can be illustrated by the fact that Norway has managed to build one of the largest sovereign funds in the world worth USD 1,200 billion for use by future generations. Only $3 \%$ of its value, significantly less than its historical net profit, should be used annually.
\end{abstract}

\section{Keywords}

JEL Classification

\section{INTRODUCTION}

Norway, as a small economy considerably open for international trade, has been producing oil and gas for more than 50 years. The country exports huge quantities of crude oil and is the world's third largest exporter of natural gas, supplying approximately 25 percent of EU gas demand. Contrary to many other natural resource abundant countries, it has avoided the resource curse due to its strong institutions. Overall, the Norwegian management of the revenues from these resources has benefited the entire nation. This paper contributes to the understanding of this success from an environmental, ethical and resource rent perspective.

During the first half of the 1970s, one seemed to have a reasonable understanding of how petroleum resources could be used to benefit society. The foundation stems from the understanding of petroleum as a non-renewable natural resource one could harvest 
resource rent from. Thus, it should be handled in a beneficiary, environmentally friendly and ethical way.

This paper seeks to find out why Norway chose to pursue a petroleum policy aiming at a qualitative better society with an emphasis on even distribution of wealth, avoiding overspending, creating a sovereign fund for future generations, and protecting the environment. The paper addresses critical historical events that shaped these values: the long tradition of dealing with environmental issues by managing natural resources, the Concession laws, and the origin of state ownership.

\section{LITERATURE REVIEW}

Noreng (1984) has argued that the Norwegian petroleum adventure to a large extent was formed without any clear strategy in advance, with some mental and ethical attitudes playing a significant role. Hanisch and Nerheim (1992) raised the issue of ethical assessments behind the development of the Norwegian petroleum policy. Their departure was an influential white paper, "The role of petroleum activities in the Norwegian society" (Finansdepartementet, 1974). The paper laid the foundation for the public debate on how the petroleum revenues should be used and what effect the petroleum activities would have on society. Many topics requiring ethical considerations were presented, including sustainability issues. The most fundamental was the concept of "building a qualitatively better society."

Another important point is that the institutional setting in Norway during the 1960s was very different from most oil countries, in particular de- veloping countries. "Oil companies, especially eager to exploit resources outside of the OPEC's dominion, did not encounter a poor country, a weak state, undeveloped social forces, or a predatory, authoritarian ruler. Instead, Norway was already a wealthy, equitable, and democratic country" (Karl, 1997, p. 216).

Østerud states that "The dilemma of the Norwegian state is this dual role as a commercial player and a political regulator, and nowhere is this dilemma more acute than in the petroleum industry" (Østerud, 2005, p. 708). In addition, he argues, one should address the spirit of cooperation within politics and the high level of trust in the Nordic countries.

Currently, oil and gas production on the Norwegian continental shelf is billed with 22 percent in ordinary taxes and 56 percent in resource rent tax, 78 percent in total. The historical development is shown in Figure 1, where special taxes and royalties and fees, inclusive en-

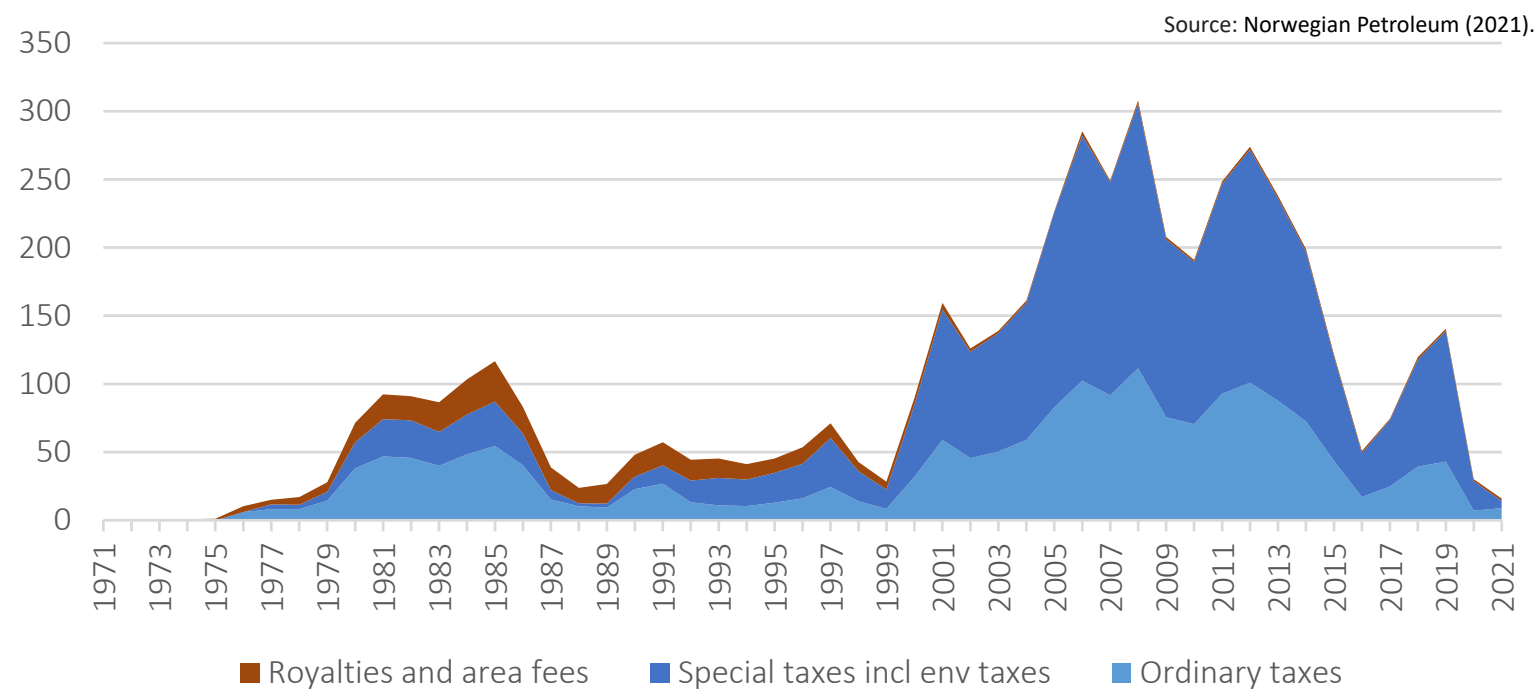

Figure 1. Taxes from oil and gas extractions in Norway 1971-2021, billion NOK 2021 values 
vironmental taxes, can be considered resource rent taxation. Due to COVID-19, the companies have paid and are paying significantly less tax in 2020 and 2021 .

Several countries with abundant natural resources have experienced the resource curse, i.e., large natural resources result in lower economic growth (Sachs \& Warner, 1995), and one could add environmental degradation. However, as shown by others, Norway has avoided the resource curse partly because of "how the Norwegian government ensured that the bulk of the oil revenues was reaped by the state" (Holden, 2013, p. 875). This paper is aimed at explaining the values behind the ethics shaping the Norwegian petroleum policy with an emphasis on good stewardship of the environment and the resource rent stemming from oil and gas extraction.

\section{METHODOLOGY}

The extraction of oil and gas gives a profit on the use of non-renewable resources, stemming from the resources themselves. This profit is called resource rent, in line with David Ricardo's definition of land rent, which is the profit one receives from the soil by utilizing it. The resource rent is understood as an extra profit given by the natural resources. Hence, one may define resource rent equal to the value of capital services rendered by natural resources, or their share in the gross operating surplus. Its value is given by the value of extraction.

\subsection{Ricardian resource rent}

The Ricardian resource rent is explained in Figure 2. Long-term marginal costs, i.e., the supply curve for a normal product is assumed to be constant, and thus, given by $c_{A}{ }^{\prime}$. The demand curve, $D$, gives an equilibrium production level at $\hat{x}$. However, for a natural resource, the long-term marginal curve is not constant but increasing as illustrated by the curve $c_{R}^{\prime}$. The reason is that the higher extraction level of the natural resource is associated with a higher long-term marginal cost. Hence, for a natural resource, the equilibrium level will be at the price level $\bar{p}$ and at the production volume $\bar{x}$. But this equilibrium generates a resource rent, which is equivalent to the blue triangle in Figure 2 and represents rents beyond a normal economic profit.

\subsection{Resource assets and resource rent}

It is common to define the assets of natural resources as the net present value of expected future use of the resources, i.e., future resource rent. To calculate the value of the resource assets, one needs the volume of production, product prices and costs. The production of oil and gas as non-renewable resources is in fact a way to consume the resource assets.

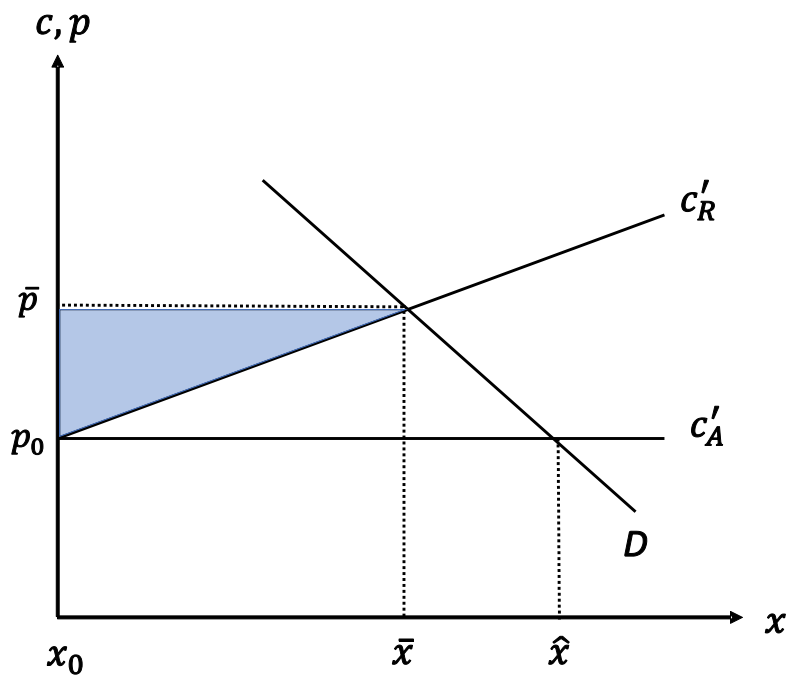

Note: The blue triangle illustrates the size of the resource rent.

Figure 2. Ricardian resource rent 
If one defines the resource asset, $W$, at the departure, 0 , as $W_{0}^{*}$ as the net present value of future resource rent with an optimal extraction of the resources, $u_{0}^{*}, \ldots, u_{\infty}^{*}$. With discretionary time one will then have an optimal asset expressed as (Aaheim, 1994):

$$
W_{0}^{*}=p u_{0}^{*}+(1+\rho)^{-1} W_{1}^{*},
$$

here $\rho$ is the discount rate. If one assumes that the real extraction of the natural resource is different from the optimal, i.e., $u_{0} \neq u_{0}$, the resource asset will change from $W_{1}^{*}$ to $W_{1}^{\prime}$ at time 1 . Hence, the real asset at time $0, W_{0}^{\prime}$, will now be:

$$
W_{0}^{\prime}=p u_{0}+(1+\rho)^{-1} W_{1}^{\prime} \text {. }
$$

Thus, the loss in resource asset due to non-optimal extraction of the resource can be found by deducting equation (2) from equation (1):

$$
\begin{aligned}
& \left(W_{0}^{*}-W_{0}^{\prime}\right)=\left[p u_{0}^{*}+(1+\rho)^{-1} W_{1}^{*}\right]- \\
& -\left[p u_{0}+(1+\rho)^{-1} W_{1}^{\prime}\right] .
\end{aligned}
$$

This gives the following equation of resource asset loss due to non-optimal resource rent extraction:

$$
\begin{aligned}
& W_{0}^{*}-W_{0}^{\prime}=p\left(u_{0}^{*}-u_{0}\right)+ \\
& +(1+\rho)^{-1}\left(W_{1}^{*}-W_{1}^{\prime}\right) .
\end{aligned}
$$

The definition implies that $W_{0}^{*}-W_{0}^{\prime}>0$. This means that it is of great importance for the government to utilize the resource rent extraction, and thus, the resource asset in a way that seems as optimal as possible for their electorate. Thus, in an institutional democracy, it will be important to monitor the resource assets and extract resources, thereby optimizing the resource rent in a way that seems ethical for their population.

\section{RESULTS}

\subsection{Policy goal: Building a "qualitatively better society"}

In the early 1960s, Norway was not ready for the petroleum age by any standard. Very few believed that there would be any petroleum in the North
Sea, and the theme was considered uninteresting. However, when the Phillips Petroleum Company approached the Norwegian authorities in 1962, requesting for a concession for the entire North Sea, the Foreign Office was uncertain regarding the answer. Furthermore, the negotiations with Denmark and UK about the borders dividing the North Sea had not yet been resolved. Additionally, they did not possess any specific knowledge about the petroleum industry.

The offer from Phillips was not accepted, and the company was not granted a sole concession. Instead, the lawyers in the Foreign Office researched Norwegian law and history and studied how natural resources had been managed as common resources. As a result, on June $21^{\text {st }}, 1963$, the state issued a law (The law on exploration and use of subsea natural resources) in which article five stated, "The (property) right to subsea natural resources belongs to the state." This simple article unquestionably stated that it was the state who legally had the property rights to the potential petroleum resources in the North Sea. At the same time, the article not only established the state as the primary stakeholder but also paved the way for the state to take an active role in the oil business.

How should we understand this argument? Part of the answer lies in the postwar zeitgeist. Their values represented a continuation of historical lines. One presumed that if there were any petroleum resources, the extraction would include resource rent, and the value of this should benefit the people. Postwar Norway was "characterized by developing the welfare state, and it is in this light we must understand how they were thinking. Even though there was no single discovered drop of oil on the Norwegian Continental Shelf, they prepared a policy where the future oil resource could be used as a tool to develop Norway further" (Skredderberget, 2015, p. 32).

In short, the state should be in control, and the property rights to the petroleum resources should not be sold to private companies. The environmental resources, in form of a resource rent, should benefit the people. However, this did not exclude using private companies in exploration and production, but the state should take part and exercise control of all steps in the supply chain. 


\subsection{The 10 oil commandments}

After the discovery of oil in the Ekofisk field in 1969, it became clear that the country would become an oil nation. However, the government seemed to be reluctant to accept this and proceeded with caution. In 1970 and 1971, white papers discussing the petroleum questions were issued (Industridepartementet, 1970, 1971). Based on these, the Standing Committee on Industry issued a Recommendation to the Parliament, including ten commandments (Table 1) laying out the principles for the Norwegian petroleum policy (Industrikomité, 1971). The committee's recommendation builds upon the following two fundamental principles: (1) the state is the owner of the petroleum resources and (2) "these natural resources should be used in such a way that they benefit the entire Norwegian society" (Industrikomité, 1971, p. 632).

Table 1. The ten oil commandments to ensure efficient utilization of resource rent from Norwegian petroleum reserves

Source: Norwegian Petroleum Directorate (2010).

\begin{tabular}{|c|c|}
\hline 1 & $\begin{array}{l}\text { National supervision and control must be ensured for all } \\
\text { operations on the Norwegian Continental Shelf (NCS) }\end{array}$ \\
\hline 2 & $\begin{array}{l}\text { Petroleum discoveries must be exploited in a way that } \\
\text { makes Norway as independent as possible of others for } \\
\text { its supplies of crude oil }\end{array}$ \\
\hline 3 & $\begin{array}{l}\text { A new industry will be developed on the basis of } \\
\text { petroleum }\end{array}$ \\
\hline 4 & $\begin{array}{l}\text { The development of an oil industry must take necessary } \\
\text { account of the existing industrial activities and the } \\
\text { protection of nature and the environment }\end{array}$ \\
\hline 5 & $\begin{array}{l}\text { Flaring of exploitable gas on the NCS must not be } \\
\text { accepted except during brief periods of testing }\end{array}$ \\
\hline 6 & $\begin{array}{l}\text { Petroleum from the NCS must, as a rule, be landed in } \\
\text { Norway, except in those cases where socio-political } \\
\text { considerations dictate a different solution }\end{array}$ \\
\hline 7 & $\begin{array}{l}\text { The state must become involved at all appropriate levels } \\
\text { and contribute to a coordination of Norwegian interests } \\
\text { in Norway's petroleum industry as well as the creation } \\
\text { of an integrated oil community that sets its sights both } \\
\text { nationally and internationally }\end{array}$ \\
\hline 8 & $\begin{array}{l}\text { A state oil company will be established that can look } \\
\text { after the government's commercial interests and pursue } \\
\text { appropriate collaboration with domestic and foreign oil } \\
\text { interests }\end{array}$ \\
\hline 9 & $\begin{array}{l}\text { A pattern of activities must be selected north of the } 62^{\text {nd }} \\
\text { parallel that reflects the special sociopolitical conditions } \\
\text { prevailing in that part of the country }\end{array}$ \\
\hline 10 & $\begin{array}{l}\text { Large Norwegian petroleum discoveries could present } \\
\text { new tasks for Norway's foreign policy }\end{array}$ \\
\hline
\end{tabular}

The most important point in the commandments is the role of the state. The state should be in control of the petroleum resources and be active in all parts of the industry, including the establishment of a state-owned oil company, Statoil. This implied that the state adopted roles both as landlord and entrepreneur (Austvik, 2012).

Secondly, petroleum resources should be used to develop a new industry, while protecting the environment at the same time (commandment no 4). The discussion regarding the potential danger to the environment was at the initial phase short and restricted to the part of transporting the oil from the sea to land.

Thirdly, exploration in the North Sea had so far been restricted to areas south of the 62 . parallel. However, the white papers address the question regarding whether oil exploration should be allowed north of the 62 . parallel, on condition that these areas had to be developed in a unique manner, protecting the vulnerable arctic environment and the relationship with the Soviet Union (commandments no 9 and 10). It is evident from the white papers that there was increasing political pressure to allow exploration north of the 62. parallel to create jobs in the northern parts of the country (Bjørklund, 2008, 2009). In 1979, the Norwegian parliament granted exploration concessions for selected fields north of the 62. parallel.

\subsection{White paper "The role of petroleum activities in the Norwegian society"}

The most important white paper was published in 1974 with the title "The role of petroleum activities in the Norwegian society" (Finansdepartementet, 1974). The white paper was of immense importance, presenting a starting point for the public debate in the years to come: "The Government is aiming to lay a foundation for a broad debate about the petroleum policy in all parts of the Norwegian people" (p. $\left.5^{\star}\right)$. It provided an overview to several dimensions of how these activities could affect both Norway and its relation to other countries:

1) democracy and control;

2) international perspectives;

3) the use of the resources and its consequences for the natural environment;

4) equality and work environment; and

5) settlements of people and the local community. 


\subsubsection{The fundamental question is ethical}

The most fundamental question in the white paper was: How should the country spend the oil money? The government's answer was to build "a qualitatively better society". "The economic opportunities must be used to create greater equality in the living standards ... to prevent social problems, and to develop a more environmental and resource-friendly production" (p. $6^{*}$ ). In other words, an environmentally friendly welfare state should be further developed, and all use of petroleum revenues should "be part of a planned transformation of the Norwegian society" (p. $6^{*}$ ).

The white paper emphasized the role of the state in all phases of the petroleum value chain. The focus on the state's role was historical and reflected a renewed nationalism after the 1972-referendum, when Norway declined to become a member of the European Community. The state represented the people: "The people have to elect bodies which must have control of all important aspects of the petroleum policy" (p. $9^{*}$ ). As part of this policy, the white paper signaled that the state could use part of the oil revenue to increase its ownership in private companies. Critical in this respect was the establishment of the state oil company Statoil, which should take part in every activity in the supply chain and every concession. It should simultaneously compete in the global oil business and be a political tool for the Parliament and the government in ensuring social responsibility and to pursue profit.
The white paper included warnings against spending the petroleum revenues too fast and for consumption only. The argument was avoiding a macroeconomic shock, but ethical questions were also present "for the sake of future generations" (p. $17^{\star}$ ). The white paper is the first place where it is explicitly stated that part of the oil revenues could be invested abroad. We can interpret this as being the seed for the Norwegian sovereign fund, i.e., the Norwegian Government Pension Fund Global (NGPF).

\subsubsection{The Norwegian Government Pension Fund - Global}

To avoid Dutch disease, i.e., high inflation due to a rapid increase in currency income, and to secure the resource rent revenue for the future generations the NGPF was founded in 1990 and came into operation in 1996. The fund is where the surplus revenues of Norwegian petroleum extraction is deposited. The establishment mirrors the idea that the extraction of oil and gas is consumption of the national asset of a non-renewable resource. To maintain the value, the money is invested abroad, and one is supposed to use the net returns only, annually expected to be three percent of its value. This is a cautious measure as the historical returns until 2020 in current terms were 6.3 percent and in real terms, i.e., after inflation and operational costs, 4.4 percent.

As seen from Figure 3, the growth of the fund has been tremendous, with the highest growth

Source: NBIM (2021).

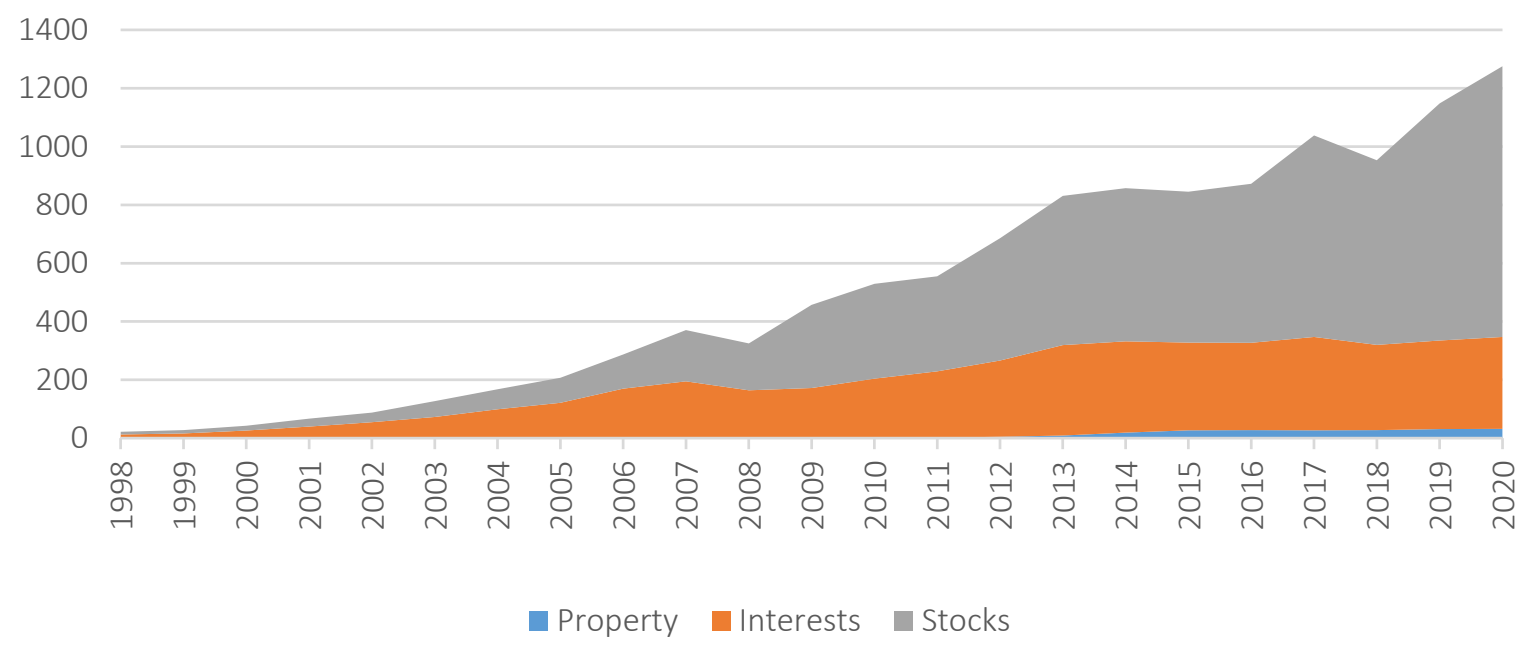

Figure 3. Value of the Norwegian Pension Fund - Global, in USD billion 
for stocks, which by the end of 2020 accounted for 72.8 percent, followed by interest investments with 24.7 percent and property with 2.5 percent.

In 1998, the fund's value was 16.9 percent of the GDP of mainland-Norway. By the end of 2020, it was close to 360 percent, as shown in Figure 4. Early in 2017, the returns of the capital of the fund for the first time exceeded the capital input. The latter has since 2013 been shrinking compared to GDP. This indicates that the net revenue from oil and gas extraction is in decline, and that in the future the returns or rent on the investments will be the key provider to the fund. A weaker Norwegian currency during the last years, partly due to less income from petroleum, has contributed significantly to the increasing value of the fund. In 2020, this contribution reached 47.6 percent of mainland GDP, compared to 99.9 percent from capital input and 211.3 percent from returns on investments. The NGPF has truly proven to be successful stewardship of the resource rent in petroleum extraction.

\subsubsection{Environmental issues}

In previous white papers, the government briefly addressed environmental issues, mostly focusing on direct pollution of oil into the sea and land. In "The role of petroleum activities in the Norwegian society," the discussion became significantly broader. "Economic growth must [...] be given a new meaning $[\ldots]$ so that it contributes to the sensible use of resources and does not destroy the funda- mental balance in nature" (p. 15*). There is no clear answer given to what this 'new content' should be. However, it is clear that preventing negative consequences of petroleum activities were given higher priority than before. Furthermore, the government advised a slow or moderate extraction pace, which would make environmental protection more manageable. Norway established the first governmental Ministry of Environment in the world in 1972.

Fisheries have always been an essential part of the Norwegian economy. Hence, there is a particular concern regarding how the petroleum activities will affect the fish resources. Some of the most critical and sensitive fish banks are located north of the 62. parallel. The implicit question was how much risk of damaging the environment is society willing to accept for extracting oil. A complicating factor was that both the US and Russia had strategic military interests in this part of the Norwegian seas, especially during the Cold War era, 1947-1991.

\subsubsection{Taking international responsibility}

The ethical question about sharing part of the petroleum wealth with developing countries was an important point to address for some of the political parties, particularly for the Christian Democrats $(\mathrm{KrF})$ :

1) "It is not acceptable that the main part of the oil revenue is used to increase our domestic standard of living. We have a moral obliga-

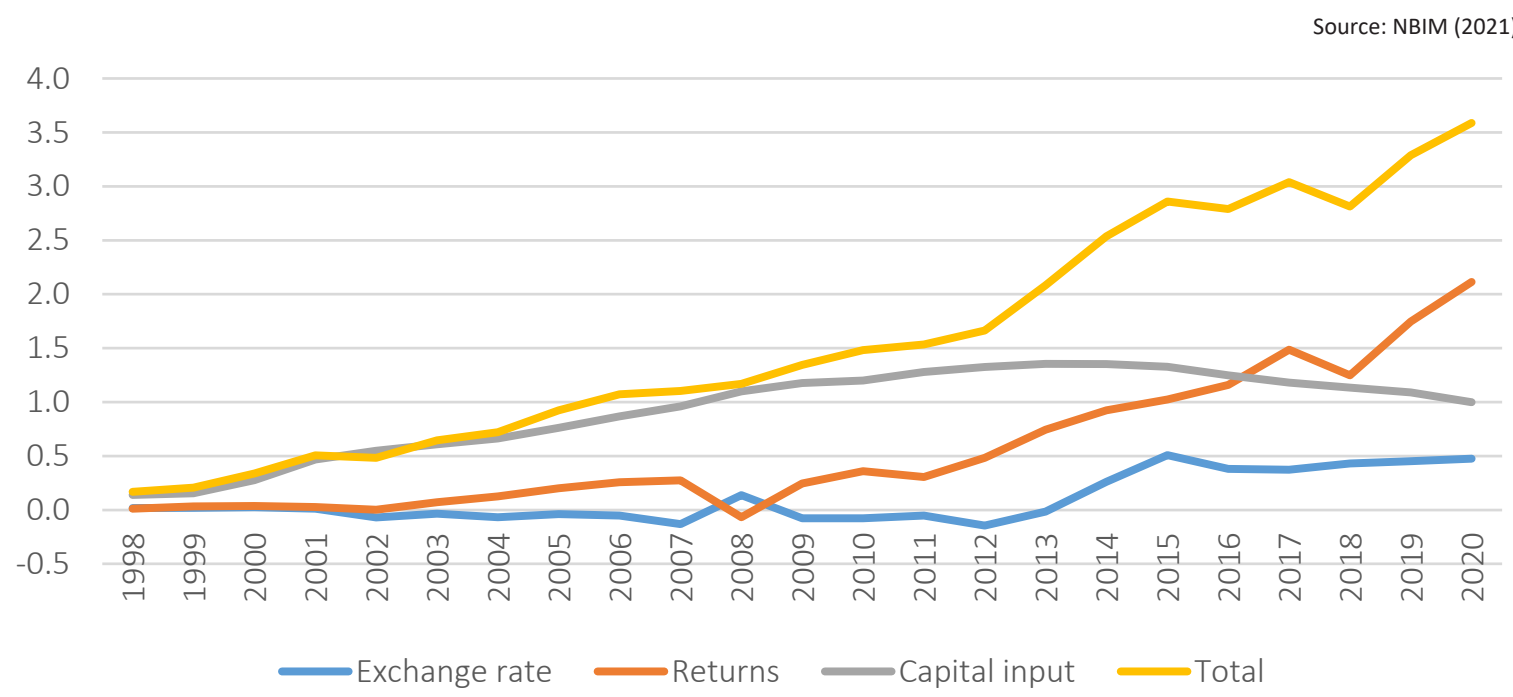

Figure 4. Value of the Norwegian Pension Fund - Global, ratio to mainland GDP 
tion to see this in view of the poverty and distress in which a too large proportion of humanity lives under" (Hanisch \& Nerheim, 1992, p. 414);

2) "We should acknowledge strong stewardship for the oil revenues because it constitutes wealth, we manage on behalf of many more than just ourselves" (Finanskomiteen, 1974, p. 19).

When reading the transcript of parliamentary debates, it becomes clear that politicians across the political spectrum addressed the ethical obligation attached to the new wealth. Indeed, the white paper itself acknowledged this as follows: "we have a special responsibility in a world characterized by fundamental economic and social inequality. We should, therefore, provide the countries that need it the most with part of the increased income" (p. 14*). One of the primary mechanisms to achieve this was to fulfill the objective of using one percent of GDP on foreign aid.

\subsubsection{Yes, we are going to be rich. However, we don't like it (yet)!}

It is not easy to summarize "The role of petroleum activities in the Norwegian society". It addresses welfare levels, egalitarianism, social problems, different stakeholders, the environment, ethics and values, societal changes, local communities, rural policy, taxation, work life, economy, consumption, investment, foreign policy, foreign trade and foreign aid. The government wanted a broad discussion involving different parts of society.

Huge personal wealth has hardly been comfortable in traditional Norwegian mentality. Historically, the country did not have a wealthy nobility as one would find in most of Europe. Instead, the prevailing value was egalitarianism. In this light, it seems natural that there is a general sentiment in the white paper warning against the future wealth and a concern regarding how this will change society. However, Noreng (1984) is very critical of the discussion and the white paper itself and claims that it was more than a policy paper.

"Morally and politically the discussion was typically in line with the old pattern of thought.
Change was perceived as evil, although it would bring greater prosperity. [...] In broad circles, oil money in itself was seen as evil. In part, this expressed a puritan attitude, with an emotional fear of being morally corrupted by quick and easy wealth. [...] This was the reason why the government did not dare to give the Norwegian people greater wealth alone, but only together with a morally sound and politically correct package. This package was called 'a qualitatively better society'. [...] a program for changing the Norwegian society in a direction inspired by a socialist and populistic thought" (Noreng, 1984, pp. 79-80).

The white paper laid the foundation for the public debate on how the resource rent in the form of revenues from oil and gas extraction should be used and what effect the petroleum activities would have on society. Did the country achieve its objective of building a qualitatively better society? Hanisch and Nerheim answer "yes" in their book on Norwegian petroleum history (Hanisch \& Nerheim, 1992). They look at social policy during the 1970s, e.g., retirement age, weekly working hours, the law on the working environment, sick leave benefits, and increased labor participation among married women. All of these variables improved. One also finds economic convergence between rural and central areas.

\section{DISCUSSION}

\subsection{Historical roots}

This section investigates historical roots of the ethical values that shaped the petroleum policy. The discussion is made along two main arguments. Firstly, there is a close connection between Norway's natural resources, open economy, and institutions. In several cases, the institutions have been established as a direct consequence of managing natural resources. The focus is on the Concessions laws and state ownership in general. Another important aspect is cooperation between the public and private sectors. To understand this, the paper examines the impact of the troubling interwar years and the labor movement during the 1930s. Secondly, the paper addresses the public's trust in a strong, non-corrupt state. 


\subsection{Natural resources and institutions}

The Norwegian economy has always utilized natural resources for domestic use and exports. Forestry, fisheries, and waterfalls have been especially important. Fisheries and forestry were already regulated before the mid- $18^{\text {th }}$ century to prevent exhaustion of the resources. There was a popular understanding of the need to regulate and preserve the renewable natural resources to avoid exhaustion. This dependence between natural resources and the economy has contributed to: "three institutional characteristics of the Norwegian business system. Firstly, significant local and regional variations in the business system have emerged because people have adapted their economic activities, their local institutions, and ways of organizing to the differences in the resource endowment. Secondly, the wide distribution of natural resources combined with topographical limits to strong centralized political and economic governance have promoted relatively autonomous and economically active local communities. Thirdly, the often-high resource rent and high value of the natural resources have promoted the state to intervene in the economy, through regulations, economic support or ownership." (Thue, 2008, p. 395)

In addition to the importance of the natural resources per se, a critical point in understanding the governing of these resources is the fact that Norway is a relatively young state, founded in 1814. Between 1380 and 1814, the country was in reality a colony under Denmark and was governed from Copenhagen (the so-called '400-year night'). Thereafter, it stayed independent, but in a personnel union under the Swedish king until 1905. The longing for independence from foreign political control and interference created a fear of giving up sovereignty, territory, and resources. Furthermore, being under foreign political control created a sense of nationalism. Both in 1972 and 1994, Norway voted 'no' in referendums to join the European Union.

\subsubsection{The Concession laws}

Norway was a late-comer in the industrialization process during the $19^{\text {th }}$ century, but "was not peripheral from a social, political, cultural or edu- cational perspective. It "became both socially and politically a free society, and [...] was deeply imbued by a Puritan Protestant ethic" (Berend, 2013, pp. 241, 242). The waterfalls, which were generating hydroelectric power, became the decisive factor in the industrialization process. They were of interest to domestic and foreign industrial companies in need of access to cheap, electrical power. Much of the extraction of Norwegian natural resources relied heavily on "foreign initiative, skill and capital" (Moses, 2005, p. 36). This was perceived as a growing problem throughout the $19^{\text {th }}$ century as national awareness and nationalism increased.

In 1906, the government issued the Concession laws preventing foreign purchase of Norwegian waterfalls. This was soon extended to include forests and mining. The laws created a heated political debate. Some argued that this was a significant change in industrial policy moving away from a liberal and open system, while others welcomed the change that made the country gain better control of the resource rent from the waterfalls. Lange writes that "the debate about the laws and the form they received revealed the existence of highly negative attitudes towards private capitalistic activity in leading political circles" (Lange, 1977, p. 314). Hence, the discussions of the concessions laws between 1906 and 1918 can be interpreted as a struggle between classical liberalism and a more active and regulatory state (Slagstad, 2001; Thue, 2008).

It is essential to understand this event for at least four reasons. Firstly, the concession laws expressed both a national skepticism regarding foreign ownership and domestic private ownership of common resources. Secondly, they created a role for the state in managing natural resources that was in line with the public sentiment at the time. Thirdly, the laws required the use of domestic labor and materials, and foreign firms were encouraged to support the domestic industry. Fourthly, they were used as inspiration when Norway discovered its petroleum resources. Hence, "it is hard to exaggerate the influence that these concession laws had on subsequent developments, [....and after discovering petroleum] these same laws were used to secure a central position for Norwegian firms until they became strong enough to fend off international competitors" (Moses, 2005, p. 37). 


\subsubsection{State ownership}

A critical factor in Norway during the $20^{\text {th }}$ century was the active role of the state in developing the society, facilitating, and investing in industrial development, especially in investing in infrastructure. The industrialization and modernization of the Norwegian society were directed by the state and were led by a group of senior public servants. "The idea that the state should actively use its resources to facilitate economic activity was established and maintained for generations" (Lie et al., 2014, p. 46).

This idea was strengthened after the Second World War, when Norway, like most West-European countries, gained belief in government planning and governance. "If democracy was to work, if it was to recover its appeal, it would have to be planned," according to Judt. This was not as detailed planning as in the Soviet Union. Instead, the state took part in "social and economic affairs. Beyond this, there were great variations, usually a consequence of distinctive national political traditions" (Judt, 2010, pp. 67-69). Historians claim that Norway was perhaps the country where the trust and belief in state intervention were strongest among the Western countries.

The discovery of petroleum gave the state new opportunities for taking an active part in business. The banking crisis at the beginning of the 1990s gave opportunities for the state to enter commercial banking. Lie argues that presently the state "is a predominant actor in the Norwegian industrial sector", with "direct ownership of the oil resources on the Norwegian continental shelf.". He explains the extent of state ownership, drawing on three major arguments: "a high level of trust in the state as a protector of common interests, a persistent lack of robust private investors, and a strong inclination to avoid a powerful foreign influence in the domestic economy" (Lie, 2016, pp. 904-905).

Lie builds this argument on the work of Sejersted, who shows that, during the $19^{\text {th }}$ century, Norway, unlike its neighboring countries, did not develop a strong elite (Sejersted, 1993, p. 171). "The Norwegian Sonderweg is characterized by the weakness of big business and the corresponding strength of the democratic petite bourgeoisie"
(Sejersted, 2011, p. 11). This "petite bourgeoisie" did not have the capacity to raise large sums of capital. Thus, the state provided capital and took an active part in the industrial development. Its role was pragmatic; the objective was to use the state's resources to solve specific problems in the society (Lie, 2016, p. 912).

\subsubsection{The labor movement}

From the 1920s, the labor movement gained a solid position in Norwegian politics, and the years between the 1930s and the 1970s were formative for what we today consider the Nordic model. That is, an economic system with a mix of socialist thinking and market economy, governed by a welfare state. Even if the Labor Party was in front molding the welfare state, it should be noted that (1) this was part of an international movement, and (2) there was support for introducing welfare benefits across the political spectrum (Gulbrandsen \& Engelstad, 2005; Østerud, 2005; Gulbrandsen, 2007).

Norwegian politics have a strong focus on cooperating across the political spectrum. In 1935, there was an agreement between the Labor Party and the Farmer's Party on how to deal with the consequences of the Great Depression. This led to the establishment of cooperation between the two largest social classes in the society (Gustafsson, 2007; Skirbekk, 2010). The social democrats accepted that there would be no revolution and "recognized the legality of Parliamentarianism" (Ihlen \& von Weltzien Hoivik, 2015, p. 114).

Secondly, the unions and the employers' association signed a Basic Agreement in 1935 on how to handle labor conflicts, standards on working hours, paid vacation and protection against unwarranted redundancies. The agreement "may be seen as results of compromises between contradictory interests and normative and ideological positions. It reflects that no parties had achieved a full breakthrough for their principal points of view" (Heiret, 2012, p. 50).

In addition to these two events, came the "disasters of the interwar decades - the missed opportunities of the 1918, the great depression [...], the waste of unemployment, the inequalities, and 
inefficiencies of laissez-faire capitalism [...], the brazen indifference of an arrogant ruling elite and the incompetence of an inadequate political class" (Judt, 2010, p. 67). Together, these events put pressure on market liberalism. "The society was perceived as a unity in which people most deeply made up a community, but where diverse groups existed with their own interests, and these groups were entitled to make claims and organize themselves" (Kjeldstadli, 2005, p. 277). The government had to ensure "that the whole was overriding the single parts and that 'third parties' should not suffer because of conflicts" (Kjeldstadli, 2005, p. 277). Kjeldstadli continues, "social welfare policy should protect the weakest and redistribute resources. Through the labor and industrial policies, one wanted to control the conflicts between the groups in the society."

The "disasters of the interwar decades" created an opportunity for the unions and the social democratic Labor Party to gain political control and govern the country in a moderate socialist direction. The state should make plans for developing the country, including economic development. The idea was for the state to plan and guide the development, when both the state and the private sector had to cooperate to reach the goals. "Both the early efforts to cope with the interwar crises and the WWII itself strengthened social and national solidarity and the quest for cooperation" (Thue, 2008, p. 441). This understanding of the benefits of cooperation between (a) different political and social groups and (b) the state and private sector became part of the public sentiment.

\subsection{In the state we trust}

While the state in Norway has a prominent role in societal life, people's trust in other people and the state is strong. Tables 2 and 3 report scores taken from the Legatum Prosperity Index and the World Value Survey.

The survey shows that almost 75 percent of Norwegians think that most people can be trusted. In comparison, the same number was 27 percent for Europe and 39 percent for the USA. All the questions in Tables 2 and 3 underscore the conclusion that Norwegians have a prominent level of trust and confidence in their fellow citizens. The same applies to important institutions in the society. Almost half of the Norwegians trust the government "Quite a lot", compared to 32 percent in the USA. A total of 71 percent of the Norwegian respondents answered "yes" on "Do you have confidence in the national government?" In the other Nordic countries 50 percent answered "yes", while for Europe the number was 39 percent. This confidence also translates into the view on corruption in society. Only 30 percent of the respondents in the Nordic countries believe that businesses and governments are corrupt, half the share of Europe.

These conclusions are supported in a more comprehensive study by Delhey and Newton (2005, p. 311). They find that the Nordic countries are exceptional with respect to trust. The Nordic countries have high scores on the main variables in their model, which are ethnic homogeneity, Protestant religion, good government,

Table 2. Popular confidence in Scandinavia and Europe

Source: The Legatum Institute (2015).

\begin{tabular}{|c|c|c|c|}
\hline Question & Europe & Denmark, Sweden, Finland, Iceland & Norway \\
\hline Do you think that most people can be trusted? (\% yes) & 27.44 & 52.20 & 74.20 \\
\hline Do you feel safe walking alone at night? (\% yes) & 69.26 & 82.58 & 88.80 \\
\hline Do you have confidence in the national government? (\% yes) & 39.41 & 50.15 & 71.00 \\
\hline Satisfied with freedom of choice? (\% yes) & 73.74 & 92.40 & 94.80 \\
\hline Do you have confidence in the judicial system? (\% yes) & 48.59 & 74.90 & 88.00 \\
\hline Do you have confidence in the military? (\% yes) & 74.48 & 81.80 & 87.00 \\
\hline Do you have confidence in the honesty of elections? (\% yes) & 53.81 & 83.85 & 93.70 \\
\hline Are the businesses and government corrupt? (\% yes) & 63.54 & 31.00 & 29.70 \\
\hline Satisfied with living standards? (\% yes) & 62.35 & 87.23 & 91.80 \\
\hline
\end{tabular}


Table 3. Popular trust and confidence in Norway and the USA

Source: World Value Survey (2014), Data accessed June 29, 2018.

\begin{tabular}{|c|c|c|}
\hline Question & Norway & USA \\
\hline Trust: Most people can be trusted (\% yes) & 73.7 & 39.1 \\
\hline Trust: Your neighborhood (\% trust completely) & 47.2 & 9.7 \\
\hline Trust: People you meet for the first time (\% trust completely) & 6.4 & 0.3 \\
\hline Confidence: Justice system (\% who answered 'A great deal') & 22.1 & 8.4 \\
\hline Confidence: The Government (\% who answered 'Quite a lot') & 49.2 & 32 \\
\hline Confidence: Parliament (\% who answered 'Quite a lot') & 56.7 & 18.1 \\
\hline Confidence: Parliament (\% who answered 'Not very much') & 33.8 & 61.4 \\
\hline Confidence: The Environmental Protection Movement (\% who answered 'Quite a lot') & 63.6 & 46.1 \\
\hline
\end{tabular}

high GDP per capita and income egalitarianism. High scores on these four variables are associated with a high level of trust in society.

Summing up this section, two historical contingencies are highlighted. The first is the "democratic capitalism Norway embraced during the $20^{\text {th }}$ century, with a large and active state sup- plemented by a huge volume of small businesses (Sejersted, 1993), as stated by Slagstad (2001, p. 529): "In 'democratic capitalism' a strong state is joined together with strong communalism, which is closely associated with the 'petite bourgeoisie' and its strong ideal on equality and democracy" The second factor is the high level of trust.

\section{CONCLUSION}

The contribution of this paper is to demonstrate the importance of combining the protection of the natural environment and ethical values with the resource rent from the extraction of petroleum in the small open economy of Norway. It discusses arguments regarding why Norway has been able to manage her petroleum resources to the benefit of the people, which is defined by the ethical goal to build a "qualitatively better society", which also includes environmental protection.

The main findings are that the accomplishment of the Norwegian petroleum policy, focusing on stewardship of the natural environment and reasonable resource rent management can be attributed to a set of values, built on historical traditions, resulting in "democratic capitalism". Within this form of petroleum policy, the state plays a key role and the trust between the state and its citizens is strong.

\section{AUTHOR CONTRIBUTIONS}

Conceptualization: Ola Honningdal Grytten, John Arngrim Hunnes.

Data curation: Ola Honningdal Grytten, John Arngrim Hunnes.

Formal analysis: Ola Honningdal Grytten, John Arngrim Hunnes.

Investigation: Ola Honningdal Grytten, John Arngrim Hunnes.

Methodology: Ola Honningdal Grytten, John Arngrim Hunnes.

Project administration: Ola Honningdal Grytten, John Arngrim Hunnes.

Resources: Ola Honningdal Grytten, John Arngrim Hunnes.

Software: Ola Honningdal Grytten, John Arngrim Hunnes.

Supervision: Ola Honningdal Grytten, John Arngrim Hunnes.

Validation: Ola Honningdal Grytten, John Arngrim Hunnes.

Visualization: Ola Honningdal Grytten, John Arngrim Hunnes.

Writing - original draft: Ola Honningdal Grytten, John Arngrim Hunnes.

Writing - review \& editing: Ola Honningdal Grytten, John Arngrim Hunnes. 


\section{REFERENCES}

1. Aaheim, A. (1994). Inntekter fra utvinning av norske naturressurser. Noen teoretiske betraktninger (Statistics Norway 94/14). Retrieved from https:// www.ssb.no/a/histstat/rapp/ rapp_199414.pdf

2. Austvik, O. G. (2012). Landlord and Entrepreneur: The Shifting Roles of the State in Norwegian Oil and Gas Policy. Governance, 25(2), 315-334. https://doi.org/10.1111/ j.1468-0491.2011.01549.x

3. Berend, I. (2013). An Economic History of NineteenthCentury Europe: Diversity and Industrialization. Cambridge University Press.

4. Bjørklund, K. (2008). Caltex-saken og norsk oljepolitikk på Svalbard fra 1960 til 1973. University of Oslo (Master's Thesis). Retrieved from https://www.duo.uio.no/ handle/10852/23703

5. Bjørklund, K. (2009). Norwegian oil policy on Svalbard: The Caltex case 1960-67. Oslo: Norwegian Institute for Defence Studies. Retrieved from https://fhs. brage.unit.no/fhs-xmlui/handle/11250/99273

6. Delhey, J., \& Newton, K. (2005). Predicting Cross-National Levels of Social Trust: Global Pattern or Nordic Exceptionalism? European Sociological Review, 21(4), 311-327. https://doi.org/10.1093/esr/jci022

7. Finansdepartementet. (1974). Petroleumsvirksomhetens plass $i$ det norske samfunn (Meld. St. nr. 25 1973-74). Retrieved from https:// www.regjeringen.no/contentasset s/695b71fb157043998a9643f72b3 ed843/stm197319740025000dddpdfs.pdf

8. Finanskomiteen. (1974). Innstilling fra finanskomitéen om petroleumsvirksomhetens plass i det norske samfunn (St. meld. nr. 25) (Innst. S. nr. 275 1973-74).

9. Grytten, O. H. (2020). Two Centuries of Economic Growth: Norwegian GDP 1816-2020 (Discussion Paper No. 10/2020). NHH Dept. of Economics. https:// dx.doi.org/10.2139/ssrn.3632902
10. Gulbrandsen, T. (2007). Elite Integration and Institutional Trust in Norway. Comparative Sociology, 6(1-2), 190-214. https://doi. org/10.1163/156913307X187441

11. Gulbrandsen, T., \& Engelstad, F. (2005). Elite consensus on the Norwegian welfare state model. West European Politics, 28(4), 898-918. https://doi. org/10.1080/01402380500217029

12. Gustafsson, H. (2007). Nordens historia: en europeisk region under 1200 år (2nd ed.). Studentlitteratur.

13. Hanisch, T. J., \& Nerheim, G. (1992). Norsk oljehistorie: Fra vantro til overmot? Oslo: Norsk petroleumsforening.

14. Heiret, J. (2012). Three Norwegian Varieties of a Nordic Model - A Historical Perspective on Working Life Relations. Nordic Journal of Working Life Studies, 2(4), 45-66. https://doi.org/10.19154/njwls. v2i4.2304

15. Holden, S. (2013). Avoiding the resource curse the case Norway. Energy Policy, 63, 870-876. https://doi.org/10.1016/j.enpol.2013.09.010

16. Ihlen, Ø., \& von Weltzien Hoivik, H. (2015). Ye Olde CSR: The Historic Roots of Corporate Social Responsibility in Norway. Journal of Business Ethics, 127(1), 109-120. https://doi.org/10.1007/s10551013-1671-9

17. Industridepartementet. (1970). Undersøkelse etter og utvinning av undersjøiske naturforekomster på den norske kontinentalsokkel m.m (Meld. St. nr. 95 1969-70). Retrieved from https://www. stortinget.no/no/Saker-og-publikasjoner/Stortingsforhandlinger/ Lesevisning/?p=1969-70\&paid $=3 \&$ wid $=\mathrm{d} \&$ psid $=$ DIVL896

18. Industridepartementet. (1971). Undersøkelser etter og utvinning av undersjøiske naturforekomster på den norske kontinentalsokkel m.m (Meld. St. nr. 76 1970-71). Retrieved from https://www. stortinget.no/no/Saker-og-publikasjoner/Stortingsforhandlinger/ Lesevisning $/$ ? $\mathrm{p}=1970$-paid $=3$ \&wid $=c \& p s i d=D I V L 418 \&$ pgid $=c \_0237$
19. Industrikomité. (1971). Innstilling fra den forsterkede industrikomité om undersøkelse etter og utvinning av undersjøiske naturforekomster på den norske kontinentalsokkelen m. $m$ (Innst. S. nr. 294 1973-1974). Retrieved from https://fido.nrk.no/aa6f9f005a5804b4d7a3c6c081c97f27bf18334c0d23d2f39bd7e5951b9b4b19/ti_oljebud.pdf

20. Judt, T. (2010). Postwar: A History of Europe Since 1945. Vintage Books.

21. Karl, T. L. (1997). The Paradox of Plenty: Oil Booms and Petro-States. University of California Press.

22. Kjeldstadli, K. (2005). Et splittet samfunn 1905-1935 (Bind $10 i$ Aschehougs Norgeshistorie). Oslo: Aschehoug.

23. Lange, E. (1977). The Concession Laws of 1906-09 and Norwegian Industrial Development. Scandinavian Journal of History, 2(4), 311-330. https://doi. org/10.1080/03468757708578925

24. Legatum Institute. (2015). The Legatum Prosperity Index. Retrieved from https://www.prosperity.com/

25. Lie, E. (2016). Context and Contingency: Explaining State Ownership in Norway. Enterprise \& Society, 17(4), 904-930. https:// doi.org/10.1017/eso.2016.18

26. Lie, E., Myklebust, E., \& Norvik, H. (2014). Staten som kapitalist: Rikdom og eierskap for det 21. århundre. Oslo: Pax Forlag.

27. Moses, J. W. (2005). Norwegian Catch-Up. Development and Globalization before World War II. Aldershot: Asgate.

28. Noreng, Ø. (1984). Olje-Norge. Det bevisstløse eksperiment. Oslo: Aschehoug.

29. Norges Bank Investment Management (NBIM). (2021). Market value. Retrieved from https://www.nbim.no/en/the-fund/ market-value/

30. Norwegian Petroleum Directorate. (2010). 10 commanding achievements. Retrieved from https://s3.amazonaws.com/ rgi-documents/e3cbbfde7c- 
90c60753b477e84627ee06dd50ae25.pdf

31. Norwegian Petroleum. (2021) The petroleum tax system. 2021: Preliminary estimations. Retrieved from https://www. norskpetroleum.no/okonomi/petroleumsskatt/

32. Østerud, Ø. (2005). Introduction: The peculiarities of Norway. West European Politics, 28(4), 705-720. https://doi. org/10.1080/01402380500216591

33. Sachs, J. D., \& Warner, A. M. (1995). Natural Resource Abundance and Economic Growth (NBER Working Paper
No. W5398). National Bureau of Economic Research. Retrieved from https://www.nber.org/system/files/working_papers/w5398/ w5398.pdf

34. Sejersted, F. (1993). Demokratisk kapitalisme. Oslo: Universitetsforlaget.

35. Sejersted, F. (2011). The Age of Social Democracy: Norway and Sweden in the Twentieth Century. Princeton University Press.

36. Skirbekk, G. (2010). Norsk og moderne. Oslo: Res Publica.

37. Skredderberget, A. (2015). Usannsynlig rik: historien om Norge og oljefondet. Oslo: Kagge Forlag.
38. Slagstad, R. (2001). De nasjonale strateger. Oslo: Pax Forlag.

39. Thue, L. (2008). Norway: a resource-based and democratic capitalism. In S. Fellman, M. J. Iversen, H. Sjögren, \& L. Thue (Eds.), Creating Nordic Capitalism. The Business History of a Competitive Periphery. Basingstoke: Palgrave Macmillan.

40. World Value Survey. (2014). World Value Survey (wave 5, 2005-2009). Retrieved from https://www.worldvaluessurvey. org/WVSDocumentationWV5.jsp 